\title{
Vertical GSHP Systems in Sweden 1978-2015 \\ - A Survey Based on the Swedish Well Database
}

\author{
Kristina Juhlin, BSc
}

\author{
Signhild Gehlin, PhD
}

\begin{abstract}
The Geological Survey of Sweden (SGU) is the Swedish government agency responsible for groundwater, geological and mineral management in Sweden. SGU provides open access geological data on rock, soil and groundwater conditions. Since 1978 over 600000 wells (water wells, GSHP boreholes, etc) have been registered in the SGU Well Database, with around 20000 new registrations per year.

Sweden is one of the leading countries in the world in developing and using ground source heat pump (GSHP) technology. Of the more than 600 000 registered wells, roughly 320000 wells are registered as GSHP boreholes. The vast majority of these GSHP boreholes are single boreholes for single-family buildings. The number of large GSHP systems with 20 boreholes or more, is estimated to 300-350 sites.

This paper uses data from the SGU Well Database to quantify and analyze the number of vertical GSHP systems reported between 1978-2015, with special focus on GSHP systems with 20 or more boreholes. Results are shown from the development of larger vertical GSHP system installments over the years, number of registrations per year, system size, average well depth, and geographical distribution.
\end{abstract}

\section{INTRODUCTION}

Since the oil crisis in the late 1970s, Sweden has been one of the world leading countries in development and use of ground source heat pumps (GSHPs). Sales statistics from heat pump and ground heat exchanger manufacturers indicate that up till today, some 500000 GSHP systems, vertical and horizontal, small and large, have been installed in Sweden over the years (Gehlin et al, 2015).

From 1978 The Geological Survey of Sweden (SGU) has administered an open access database on drilled wells in Sweden The SGU Well Database was a result of a new regulation from 1975 (SFS 1975: 424, SFS 1985: 245). By law, all wells installed must be registered with the Geological Survey of Sweden. The law states that it is the well drillers who are obliged to submit data on the installed wells to SGU. In Sweden there is no law that says that the borehole must be grouted. Therefore almost all wells in Sweden are groundwater-filled, with casing a few meters into the bedrock, due to the cost difference. This is also why the boreholes are referred to as wells in the SGU database. Consultants and others who undertake investigations of wells are also obliged to submit data to the database. The database provides information to well drillers and other people interested in e.g. soil depth, which can be associated with construction of drilled wells 
(SGU 2016a). As the law to register water wells was established in 1975, wells drilled prior to 1975 are typically not found in the Well Database. SGU acknowledges that although the number of un-registered new wells are believed to decrease with easier registration procedures and increasing awareness of the regulation and the database, there are still a large number of drilled wells missing in the database. By the end of 2015, more than 600000 wells had been registered in the database, but due to delays in registration or neglected registrations, some $20 \%$ of all existing wells in Sweden are believed to be missing in the database (Gierup 2016).

Before the digital era all new registrations were sent to SGU by mail in paper form. The companies typically accumulated all drilling protocols from one year before sending them to SGU. Today well registrations to SGU are usually made digitally in association with the drilling project. SGU built the application for online registration in 2011, but even before that it was possible to register digitally. In the past couple of years around $60 \%$ of the new well registrations were done digitally (Gierup 2016). Figure 1 shows the average time passed between the drilling of a well and the date when the well was registered in the database. The diagram is based on all wells registered to SGU, not just energy wells. The delay in time has decreased thanks to the online registration application. Figure 2 shows the number of new wells drilled each year since 1980. The big wave of GSHP system installations in the early 2000's was due to high oil prices in Sweden (Barth et al. 2012). At that time around 30000 wells were installed annually. Today around 20000 wells are registered annually (SGU 2016).

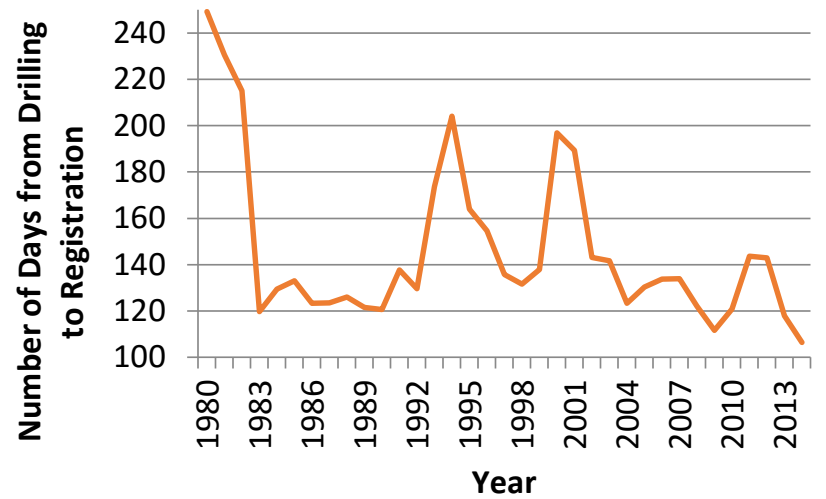

Figure 1 Average number of days from drilling to registration (SGU Well database, 2015)

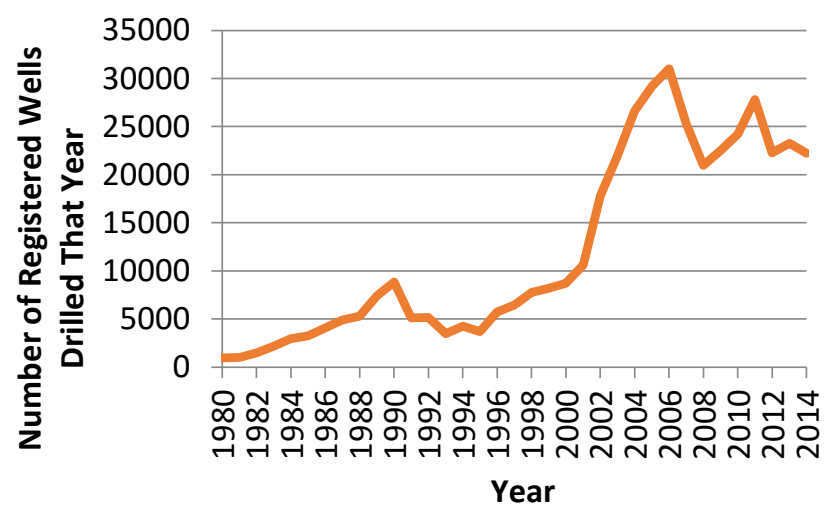

Figure 2 Number of registered wells drilled that year (SGU Well database, 2015)

In the SGU Well Database, well types are categorized by their purpose; individual water use (household, cottages, smaller farms), irrigation wells, industrial water wells, observation wells, wells for large agricultural water use, community water use (at least 10 households), energy wells (heat and/or cooling), and other usage (SGU 2015 a). The focus in this paper is on wells drilled for energy extraction or injection. These wells are identified with the capitals ENE in the database. By the end of 2015 around 320000 wells were registered as energy wells in the database. Only vertical GSHP systems (extracting heat or cold from groundwater or ground) are registered in the database. No horizontal GSHP systems are included.

In 2013 Andersson et al. (2013) estimated the number of large systems with at least 20 active wells per site as 400 systems in Sweden. Compared to the new aggregated SGU Well database data in this study the number of larger vertical GSHP systems in Sweden at the time was overestimated. Around 300 registered facilities with 20 wells or more were identified in the SGU Well Database in this study. However, this number is likely to be underestimated due to neglected and delayed registrations. Given Gierup's (2016) estimate that $20 \%$ of Swedish wells are missing from the database, the Andersson, et al. (2013) estimate of about 400 systems with 20 or more wells seems reasonable.

In this study, the focus has been on vertical GSHP systems with at least 20 wells. This system size was chosen as that would be the size required for larger facilities such as hospitals, schools, commercial buildings, large residential 
buildings etc.

\section{METHOD}

From the SGU's Well Database some 356,463 energy wells were extracted. Of these wells, 9368 wells belong to systems with 20 or more boreholes, at a total of 292 sites. The following information was extracted for each of these sites:

- Geographical region

- Name of the property

- Number of wells

- Individual well depth (m)

- Total depth of all the wells at the site (m)

- Year of installation

For a majority of the wells there is information on property name, year of installation, number of wells at site, depth of individual well, SWEREF 99 TM coordinates etc. The SWEREF 99 TM are coordinates that give you the exact latitude and longitude and are used in Sweden at a national level, dividing Sweden into twelve regions (Lantmäteriet 2016). This makes the coordinates more precise than using all of Sweden as one region. The only information that was missing from a few systems was the year of registration or the coordinates.

The data collected from the SGU Well Database was compared with information provided by drilling companies, GSHP contractors, and property owners. By comparing the SGU data with the information provided by the companies, some missing data could be added. Some of the systems that were listed by drilling companies were not found in the SGU's Well Database. In some cases this proved to be explained by the fact that for some larger sites the borefield was registered in portions at different times, and then show up as separate projects in the database.

\section{RESULTS}

The compiled list with 292 vertical GSHP systems with at least 20 active wells, extracted from the SGU's Well Database was used for studying the historical development of larger vertical GSHP systems in Sweden, with regard to number of registrations per year, system size, average well depth, and geographical distribution.

\section{Number of New Installations per Year}

During the first twenty years (1978-1998) of well registrations, between 1-3 new larger GSHP systems were registered annually. Over the last decade, however, between 20 and 30 new larger GSHP systems have been registered annually. The decreasing numbers in 2014-2015 are at least partly due to the delayed registration to SGU Well Database (Figure 3). 


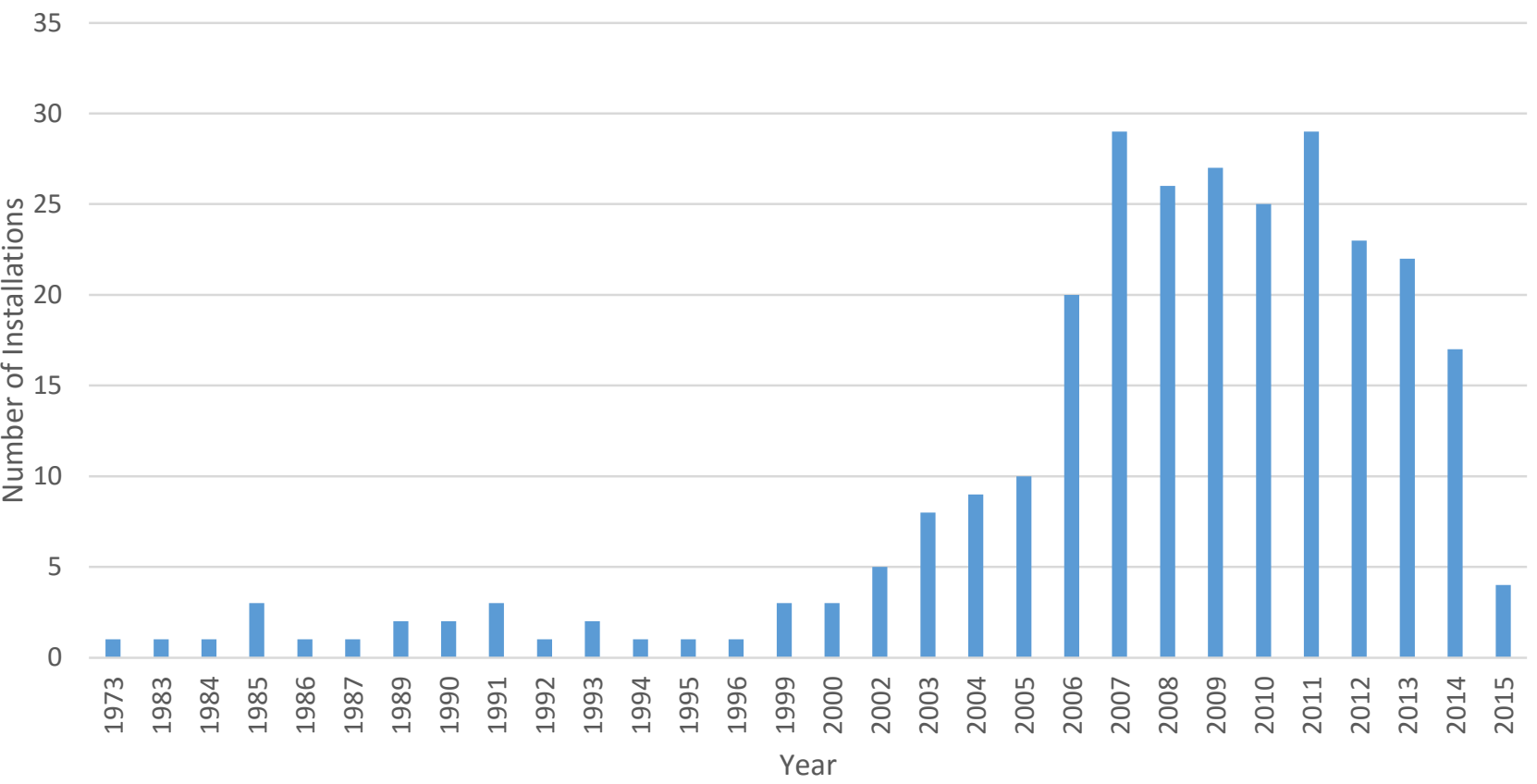

Figure 3 Installation trend of larger (20 wells or more) GSHP systems. 2014 and 2015 records may be incomplete due to registration delays. (SGU Well database, 2015)"

Figure 3 shows the growth of the market for larger vertical GSHP systems during the 2000's. With more knowledge in technology, increased interest in environmental certification for a property, and a cheaper energy solution the interest for installing vertical GSHP systems has grown in Sweden (Barth, et al. 2012).

\section{Size of Vertical GSHP System}

Not only has the number of larger GSHP systems installed per year increased, but there is also a trend towards increasing system size. The largest vertical GSHP system in Sweden today is located at Karlstad University Campus, and was completed in 2014 (Gehlin, et al. 2015, Akademiska Hus 2014). 203 wells were drilled with a total of 48,000 drilled meters. 
In the past years, most larger vertical GSHP systems have had between 20-30 wells per site (Figure 4). The number of wells per site has grown and today the average size of a larger vertical GSHP system registered in the well database is around 60 wells per site (SGU 2015 b).

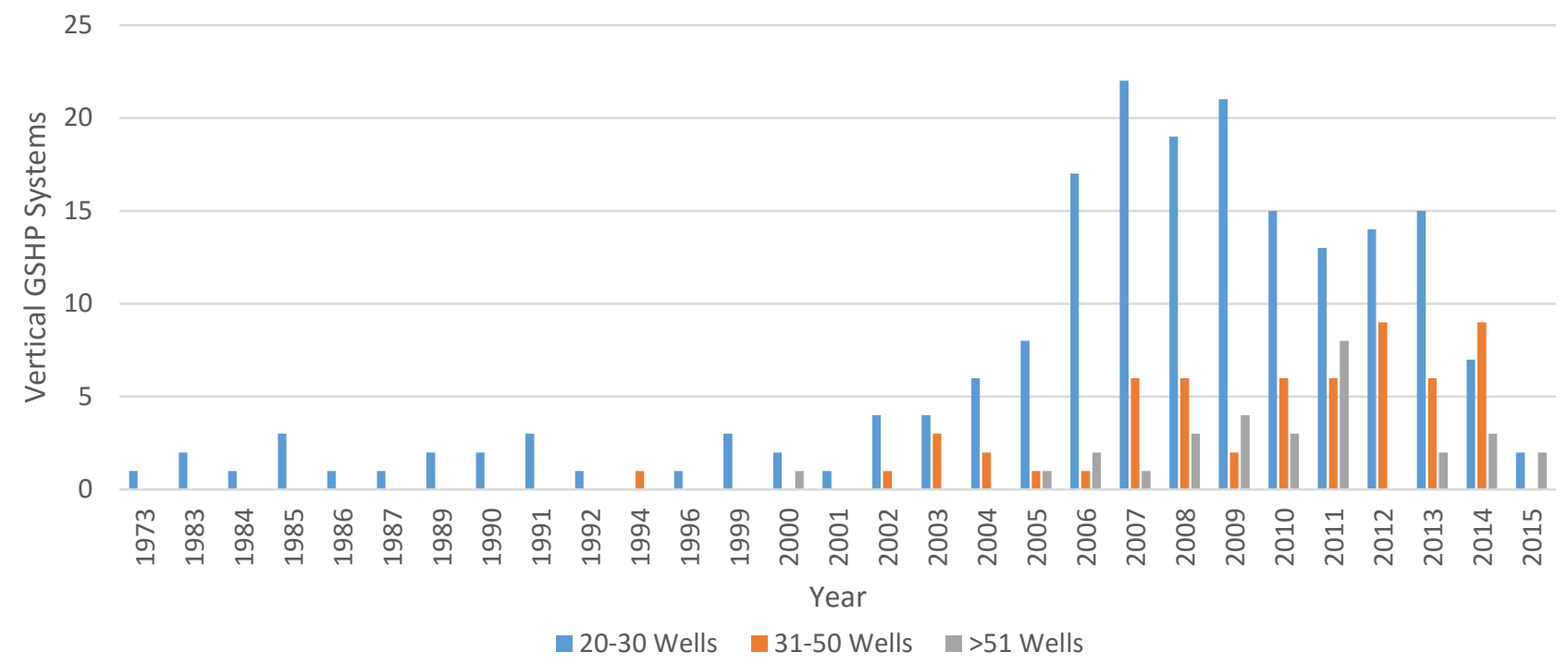

Figure 4 Development of GSHP system size over the years.

\section{Depth of Well Drilling}

In the 1980's and 1990's boreholes for GSHP systems were rarely drilled to a depth exceeding $180 \mathrm{~m}$. Since then, drilling equipment and drilling technique have developed rapidly, making possible significant increases in drilled well depth. Today boreholes for larger GSHP systems typically reach $250 \mathrm{~m}$ depth, and even $300 \mathrm{~m}$ deep boreholes are becoming more frequent for these systems. Figure 5 shows the average borehole depth for GSHP systems in Sweden over time. The average borehole depth for all sizes of GSHP systems has increased from around $120 \mathrm{~m}$ in the 1980's to $192 \mathrm{~m}$ in 2015. For GSHP systems with 20 boreholes or more, the average borehole depth has increased from around $170 \mathrm{~m}$ in the 1980's to $230 \mathrm{~m}$ in 2015. Boreholes for GSHP systems with 20 boreholes or more account for $0,03 \%$ of the total number of boreholes of all sizes of GSHP systems in the SGU database.

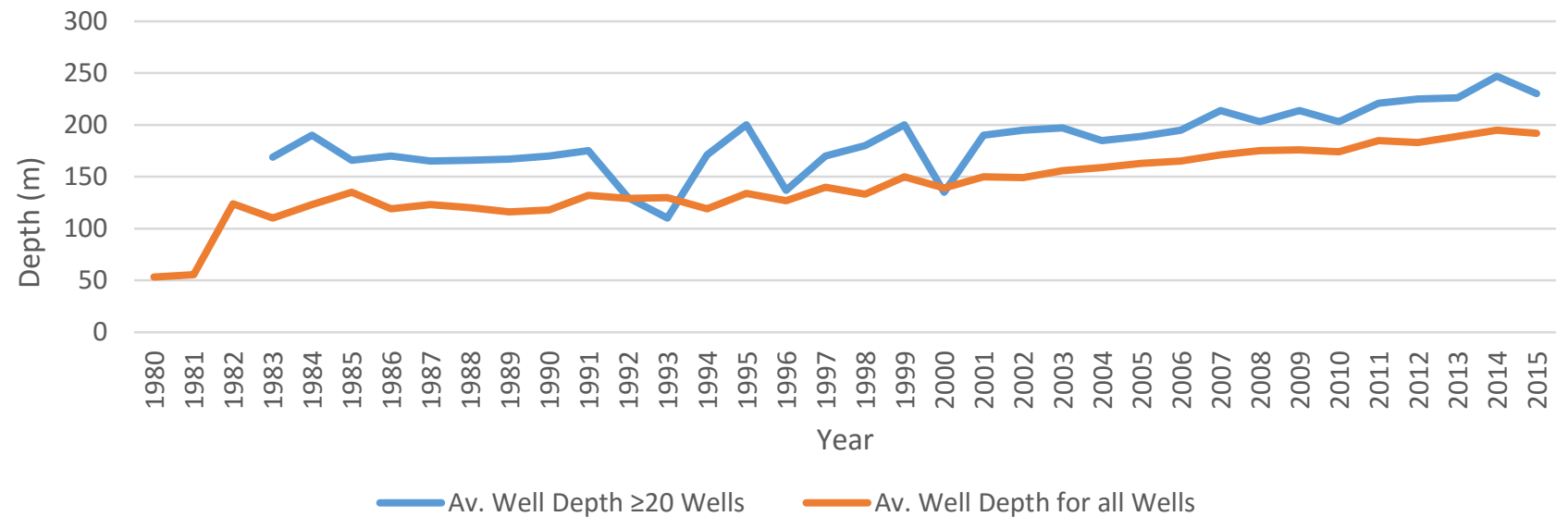

Figure 5 Development of borehole depth for vertical GSHP systems in Sweden. 


\section{Geographical distribution}

The geographical distribution of larger vertical GSHP systems in Sweden is uneven. The regions with the largest cities, such as Stockholm County, Uppsala County and Västra Götaland County, have the greatest proportion of larger GSHP systems than the rest of the country (Figure 6).
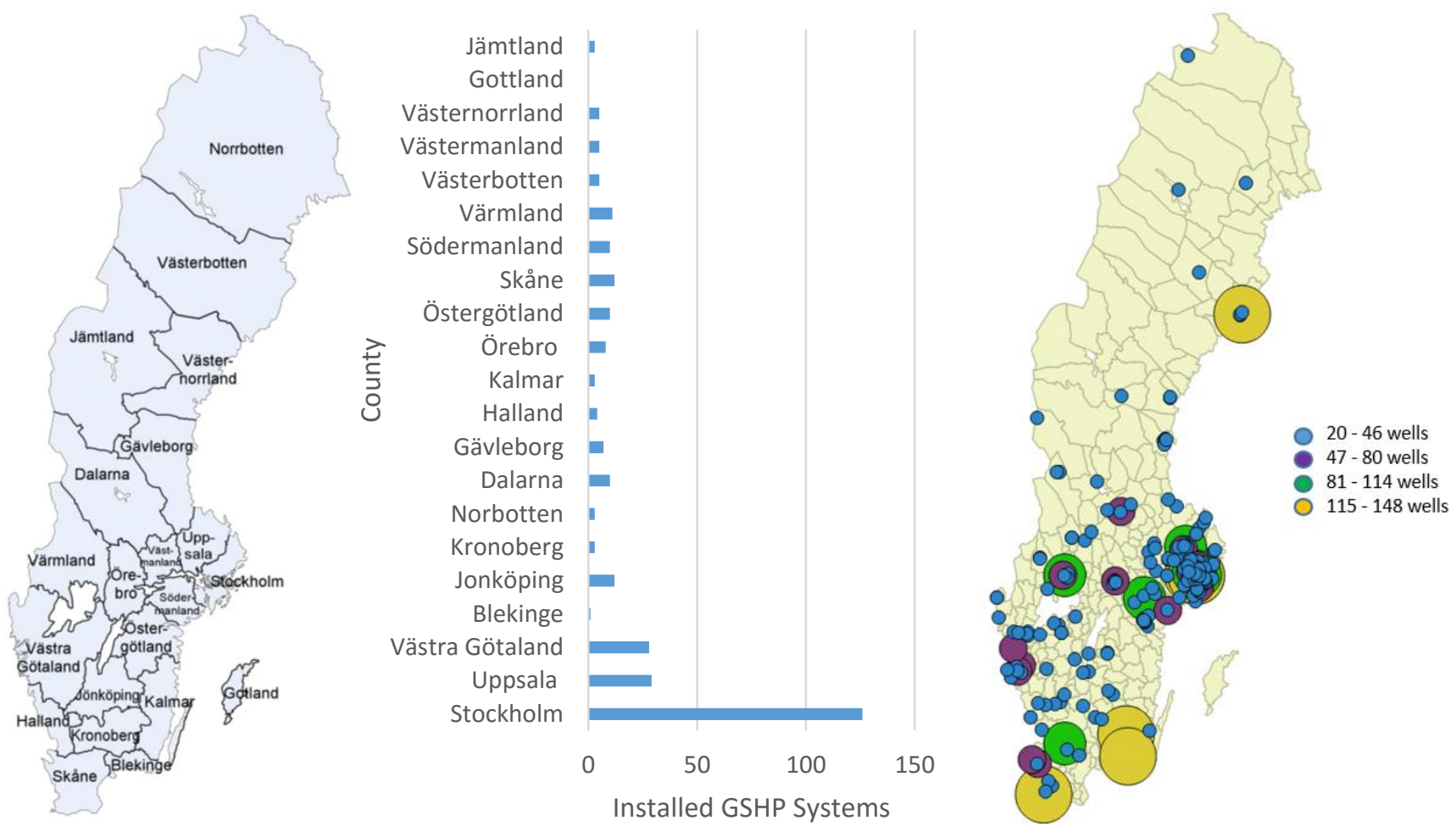

Figure 6 Distribution of large vertical GSHP systems in Sweden.

Figure 7 Geographical distribution and system size.

The largest number of energy wells are located in the more densely populated regions in Sweden, such as the Stockholm area. In the Stockholm region there are over 4000 wells (over $40 \%$ of all GSHP systems) spread over 130 sites with larger vertical GSHP systems.. The two regions with the second largest number of vertical GSHP systems, Uppsala and Västra Götaland, have around 30 installations with a total of 850 wells in each region. They each correspond to around $10 \%$ of all installed systems.

Figure 7 confirms that the majority of the larger vertical GSHP systems are found around the Stockholm area. However, the largest installations, for example Sweden's largest Karlstad University Campus with 203 wells, are also found in other regions. The Karlstad University Campus GSHP system does not show as a yellow circle in Figure 7, which may be due to registration of the borefield in separate sections, so that the total system does not register as one large system in the SGU's Well Database. 
While the number of large vertical GSHP systems increases in the more densely populated areas, such as Stockholm, there is also an increasing trend in the other regions (Figure 8a, 8b). In Stockholm County there is now around 130 installed vertical GSHP systems with at least 20 wells per site, and in Jönköping County 11 larger GSHP systems are registered.

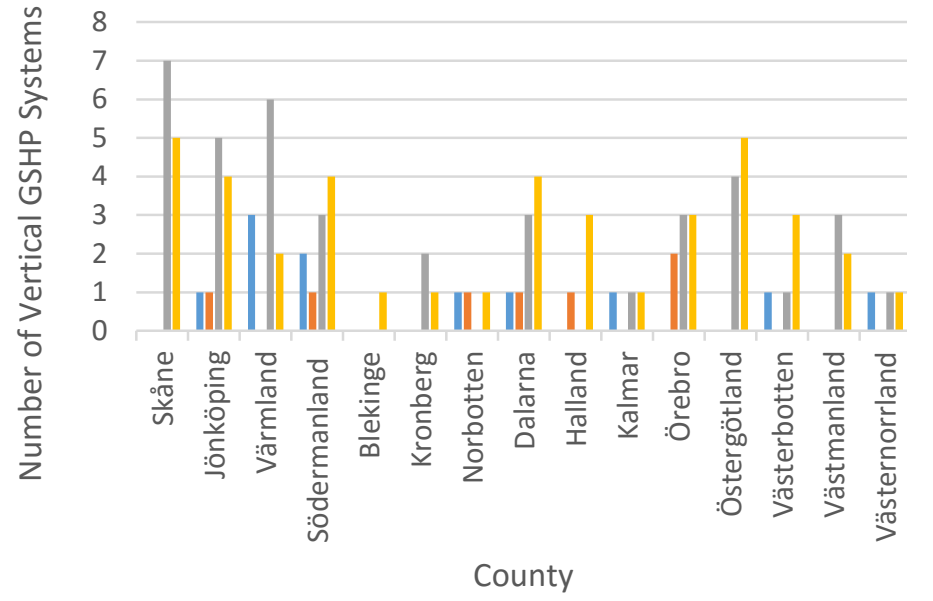

\#1973-2000 -2001-2005 $\square$ 2006-2010 $\square 2011-2015$

Figure 8a Registered large GSHP systems in the less populous counties of Sweden.

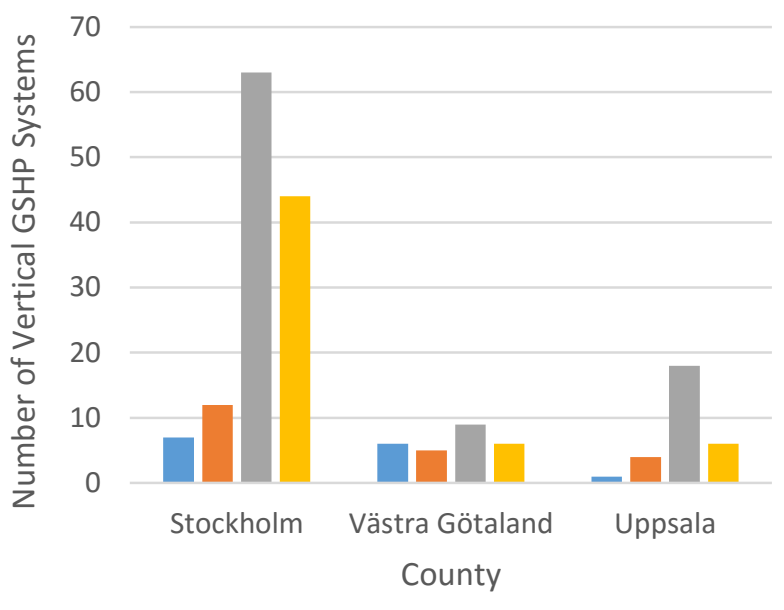

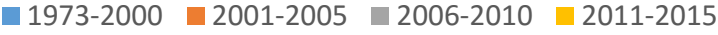

Figure 8b Registered large GSHP systems in most populous counties of Sweden.

\section{Type of Building with Installed GSHP System}

When comparing building types for the large GSHP systems, most of the registered systems are serving residential buildings (Figure 9). In the last year residential buildings, mostly apartment buildings with many apartments, have installed more large vertical GSHP systems (Figure 10). Commercial buildings such as hardware stores, local business etc. is the second largest group. The public sector (hospitals, schools etc.) is the smallest fraction.

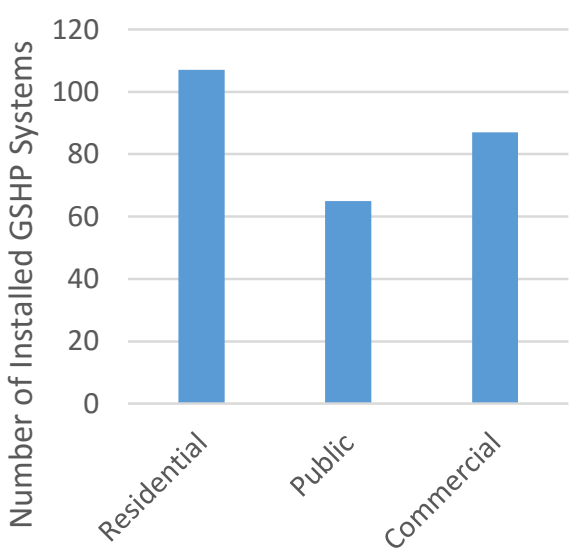

Type of Building

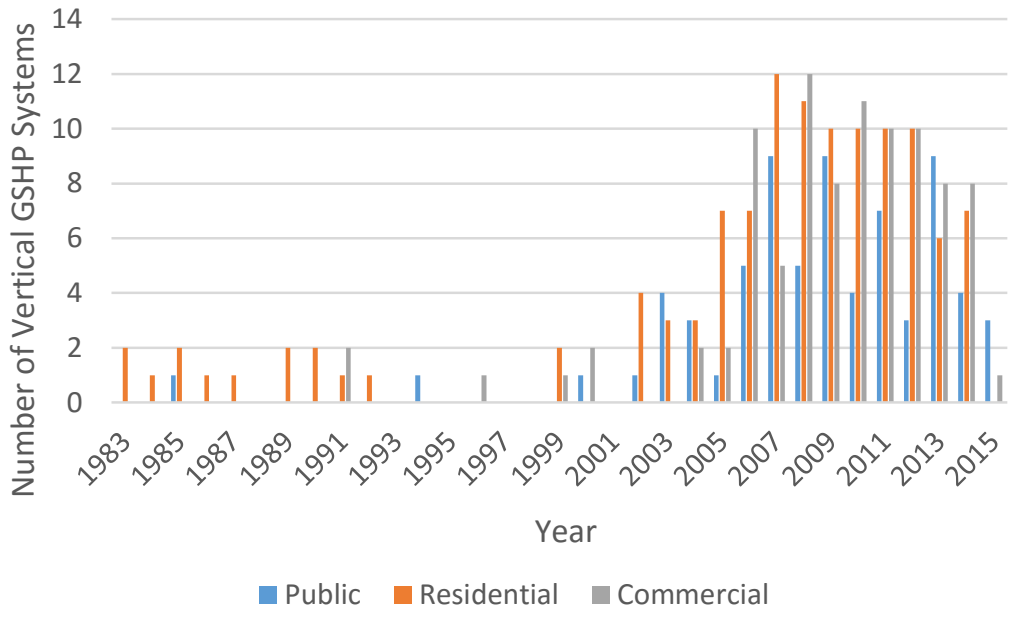

Figure 9 Building type served by a large vertical GSHP system.

Figure 10 Trend of building type served by large vertical GSHP system over the years. 


\section{CONCLUSION}

Sweden was one of the pioneering countries in the development and use of geothermal energy in the 1970s and 80s. This new statistical data on larger (>20 wells) vertical GSHP systems in Sweden gives an overview of how larger GSHP systems have been established in different regions in Sweden, and how the GSHP market has developed in recent years.

This study shows that the trends of size, number, and geographical distribution of larger vertical GSHP systems are increasing in the country. The trend of installing large vertical GSHP systems started in the early 2000's but it is only in the past ten years the number of systems have increased to above 25 new installations per year.

The study also gives an idea of the types of buildings that use large vertical GSHP systems. Residential, public, and commercial buildings have all increased in their use of GSHP systems, and the largest increase is seen for the residential sector.

There are three main sources of error in this study: missing data from early development, registration not submitted, and delayed registration. The processing of the well database data on energy wells also shows that several of the well-known systems with more than 100 boreholes are not registered as one project, but as several portions of the borehole field. With the new web application for registering online, the quality of the data may improve over time.

For further studies, similar data can be collected from other countries well archives, especially in Europe, to compare the evolution and usage of larger vertical GSHP system for that country.

\section{REFERENCES}

Akademiska Hus. 2014. Karlstad Universitet först $i$ Europa som självförsörjande med värme och kyla. Available online at: http://www.akademiskahus.se/aktuellt/nyheter/2014/11/karlstads-universitet-sjalvforsorjande-med-varme-och-kyla/

Andersson, O., Ekkestubbe, J., Ekdahl, A. 2013. UTES (Underground Thermal Energy Storage)—Applications and Market Development in Sweden. Malmö: Sweco Environment. Available online at:

http://www.davidpublishing.com/davidpublishing/Upfile/5/12/2013/2013051284542249.pdf

Barth, J., Andersson, O., Nordell, B., Hellström, G., Berg, M., Gehlin, S., Frank, H., Risberg, G., Nowacki, J-E. 2012. Geoenergi $i$ sambället - En viktig del $i$ en hållbar energiförsörnining. Lund: Geotec - Svenska Borrentreprenöers Branchorgnisation. Available online at: http://www.fab.w.se/wp-content/uploads/Geoenergin-i-samh\%C3\%A4llet.pdf

Gehlin, S., Andersson, O., Alm, P-G., Rosberg, J-E. 2015. Country Update for Sweden. Proceedings World Geothermal Congress 2015. Melbourne, Australia, 19-25 April 2015.

Gierup, J. 2016. Ground and Groundwater - Groundwater Surveillance at Geological Survey of Sweden.

Lantmäteriet. 2016. Sweref 99, projections. Available online at: https://www.lantmateriet.se/en/Maps-and-geographic-information/GPS-and-geodetic-surveys/Referencesystems/Two-dimensional-systems/SWEREF-99-projections/ [08-26-2016]

SFS 1975:424. Lag (1975:424) om uppgiftsskyldighet vid grundvattentäktsundersökning och brunnsborrning. Available online at: http://www.riksdagen.se/sv/dokument-lagar/dokument/svensk-forfattningssamling/lag-1975424-omuppgiftsskyldighet-vid_sfs-1975-424

SFS 1985:245 Lag (1975:424) om uppgiftsskyldighet vid grundvattentäktsundersö̈kning och brunnsborrning. Available online at: http://www.riksdagen.se/sv/dokument-lagar/dokument/svensk-forfattningssamling/lag-1975424-omuppgiftsskyldighet-vid_sfs-1975-424

SGU. 2015 a. Produkt: Brunnar. Organisationsnr. 202100-2528

SGU's Well Database 2015 b. Available online at: http://resource.sgu.se/oppendata/grundvatten/brunnar-nedladdning.xml Stamming, J. 2010. Borrbålslager slog ut fjärrvärmen I världens miljövanligaste sjukhus. In Svensk GeoEnergi nr. 2, p. 17. Available online at: http://media.geoenergicentrum.se/2014/11/svgeo_2_2010.pdf 